\title{
Teaching NeuroImages: A case of Vogt-Koyanagi- Harada disease with bilateral retinal detachment
}

Mona Al Banna, MBBCh BAO, MSc(Res), Stephanie Reeder, MD, Malik Ghannam, MD, Jetter Robertson, DO, and Amber Stutz, MD

Neurology ${ }^{\circledR}$ 2019;93:e421. doi:10.1212/WNL.0000000000007830
Correspondence

Dr. Al Banna

malbanna@umn.edu

Figure Radiologic findings in Vogt-Koyanagi-Harada disease

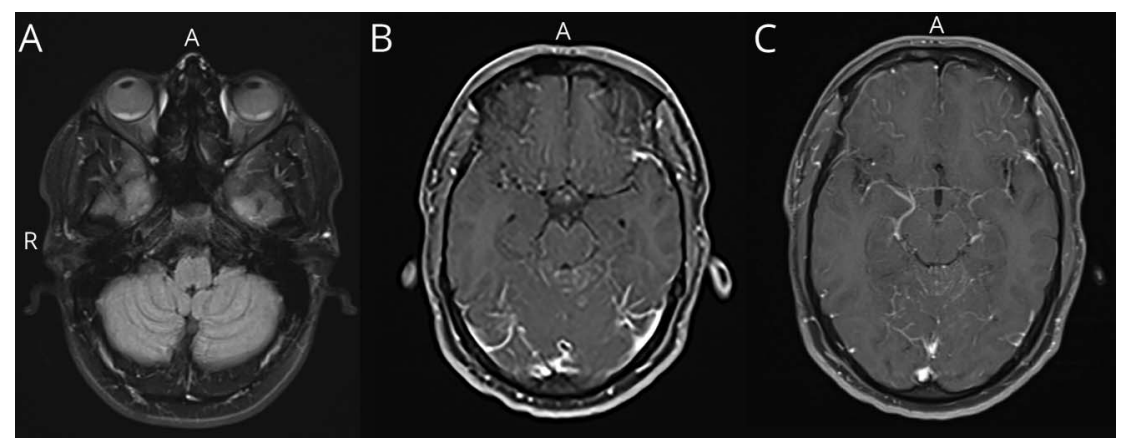

(A) Fluid-attenuated inversion recovery MRI shows bilateral serous retinal detachments and bilateral retinal/choroid thickening. (B, C) T1 postcontrast images show leptomeningeal enhancement most pronounced along the inferior aspect of the frontal lobes and in the superior aspect of the medial cerebellum.

A 28-year-old East African man with progressive visual impairment and keratitis presented with new symptoms including headache, nausea, disequilibrium, tinnitus, and right leg paresthesias. MRI showed bilateral retinal detachments and diffuse leptomeningeal enhancement (figure). Lumbar puncture showed lymphocytic pleocytosis and elevated protein. His clinical picture was consistent with Vogt-Koyanagi-Harada (VKH) disease: an autoimmune inflammatory disorder with ocular, auditory, skin, and neurologic involvement. ${ }^{1} \mathrm{VKH}$ disease is more common in Asian, Middle Eastern, and Hispanic populations. ${ }^{1}$ Treatment includes early high-dose corticosteroids with prolonged taper over months. ${ }^{1,2}$ His symptoms improved following high-dose methylprednisolone.

\section{Author contributions}

M. Al Banna: drafting/revising the manuscript, data acquisition, study concept or design, accepts responsibility for conduct of research and final approval. S. Reeder: drafting/revising the manuscript, data acquisition, analysis or interpretation of data, accepts responsibility for conduct of research and final approval, acquisition of data. M. Ghannam: data acquisition, study concept or design, accepts responsibility for conduct of research and final approval, acquisition of data. J. Robertson: drafting/revising the manuscript, analysis or interpretation of data, accepts responsibility for conduct of research and final approval, study supervision. A. Stutz: data acquisition, accepts responsibility for conduct of research and final approval.

\section{Study funding}

No targeted funding reported.

\section{Disclosure}

The authors report no disclosures relevant to the manuscript. Go to Neurology.org/N for full disclosures.

\section{References}

1. Andreoli CM, Foster CS. Vogt-Koyanagi-Harada disease. Int Ophthalmol Clin 2006;46:111-122.

2. Rajendram R, Evans M, Rao NA. Vogt-Koyanagi-Harada disease. Int Ophthalmol Clin 2005;45:115-134.

\section{MORE ONLINE}

$\rightarrow$ Teaching slides

links.lww.com/WNL/

A929 


\section{Neurology}

\section{Teaching NeuroImages: A case of Vogt-Koyanagi-Harada disease with bilateral retinal detachment}

Mona Al Banna, Stephanie Reeder, Malik Ghannam, et al. Neurology 2019;93; 421

DOI 10.1212/WNL.0000000000007830

This information is current as of July 22, 2019

\section{Updated Information \& Services}

References

Subspecialty Collections

Permissions \& Licensing

Reprints including high resolution figures, can be found at: http://n.neurology.org/content/93/4/e421.full

This article cites 2 articles, 0 of which you can access for free at: http://n.neurology.org/content/93/4/e421.full\#ref-list-1

This article, along with others on similar topics, appears in the following collection(s):

All Neuro-ophthalmology

http://n.neurology.org/cgi/collection/all_neuroophthalmology MRI

http://n.neurology.org/cgi/collection/mri

Retina

http://n.neurology.org/cgi/collection/retina

Information about reproducing this article in parts (figures,tables) or in its entirety can be found online at:

http://www.neurology.org/about/about_the_journal\#permissions

Information about ordering reprints can be found online:

http://n.neurology.org/subscribers/advertise

Neurology ${ }^{\circledR}$ is the official journal of the American Academy of Neurology. Published continuously since 1951, it is now a weekly with 48 issues per year. Copyright (O 2019 American Academy of Neurology. All rights reserved. Print ISSN: 0028-3878. Online ISSN: 1526-632X.

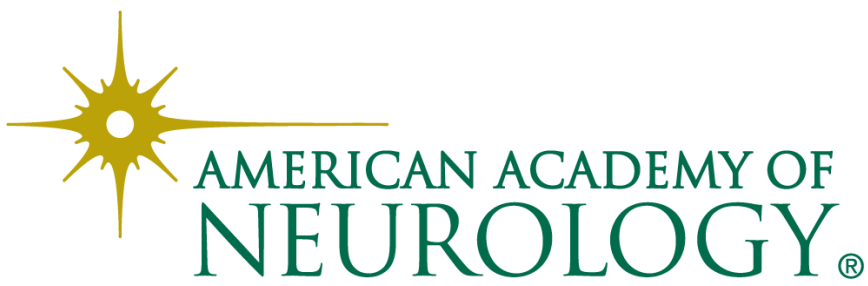

